Data on patients admitted to the National Leprosarium at Carville, La., show that leprosy in the United States is concentrated in a few areas of a few States. Nevertheless, the disease may appear in any section of the country.

\title{
Leprosy in the United States
}

\author{
BY L. F. BADGER, M.D.
}

$\mathrm{T}$ HE EARLIEST available reference to leprosy in the United States is found in Romans' Concise Natural History of East and West Florida, which reports the occurrence of the disease in that area as early as $1758(1)$. By 1766 , the disease was sufficiently prevalent to cause the Spanish commissioner of Louisiana to establish a leprosarium near the mouth of the Mississippi River. From this evidence, it may be assumed that leprosy has existed in this country for at least 200 years.

The disease has been reintroduced frequently since its first appearance; primarily from Europe and $A$ frica during the early years; later, from Asia; and, since the acquisition of extraterritorial possessions, from the Caribbean and Pacific islands.

The prevalence of leprosy in the United States, past or present, is difficult to determine. Many cases have not been recognized, and some cases known to physicians have not been reported. No nationwide case-finding program

Dr. Badger since 1949 has been chief of the Leprosy Control Unit, Communicable Disease Center, Public Health Service, Atlanta, Ga. In most of his assignments during his 24-year career with the Service he has been concerned with leprosy investigation and control work.

Vol. 70, No. 6, June 1955 has ever been conducted. However, an idea of the number of cases in recent years can be obtained from the records of the National Ieprosarium at Carville, La. From the opening of that institution in early 1921 through 1953 , 1,465 individual patients were admitted. One or more patients were admitted from 40 States and the District of Columbia (fig. 1). Thus, the disease may appear in any section of the country. (The State from which admitted was not recorded for four patients.)

Of the 1,465 patients, 637 ( 43.5 percent) were foreign born and 822 (56.1 percent) were American born. The birthplace of six patients is not known. Generally, throughout the 33year period, the number of American-born patients exceeded the number of foreign-born patients (fig. 2). (As used in this report, foreign born applies to patients born outside continental United States, and American born, to patients born within continental United States.)

Most of the patients, 1,204 (82.4 percent), were admitted from the States of New York, Florida, Louisiana, Texas, and California. From Florida, Louisiana, Texas, and California, States in which the disease has been considered endemic, $1,0+6$ (71.6 percent) were admitted. (Although leprosy is no longer held to be endemic in California, for the purpose of this review California is classed as it was in the past.) The majority of the California pa- 
Figure 1. States from which patients were admitted to the National Leprosarium, $1921-53$.

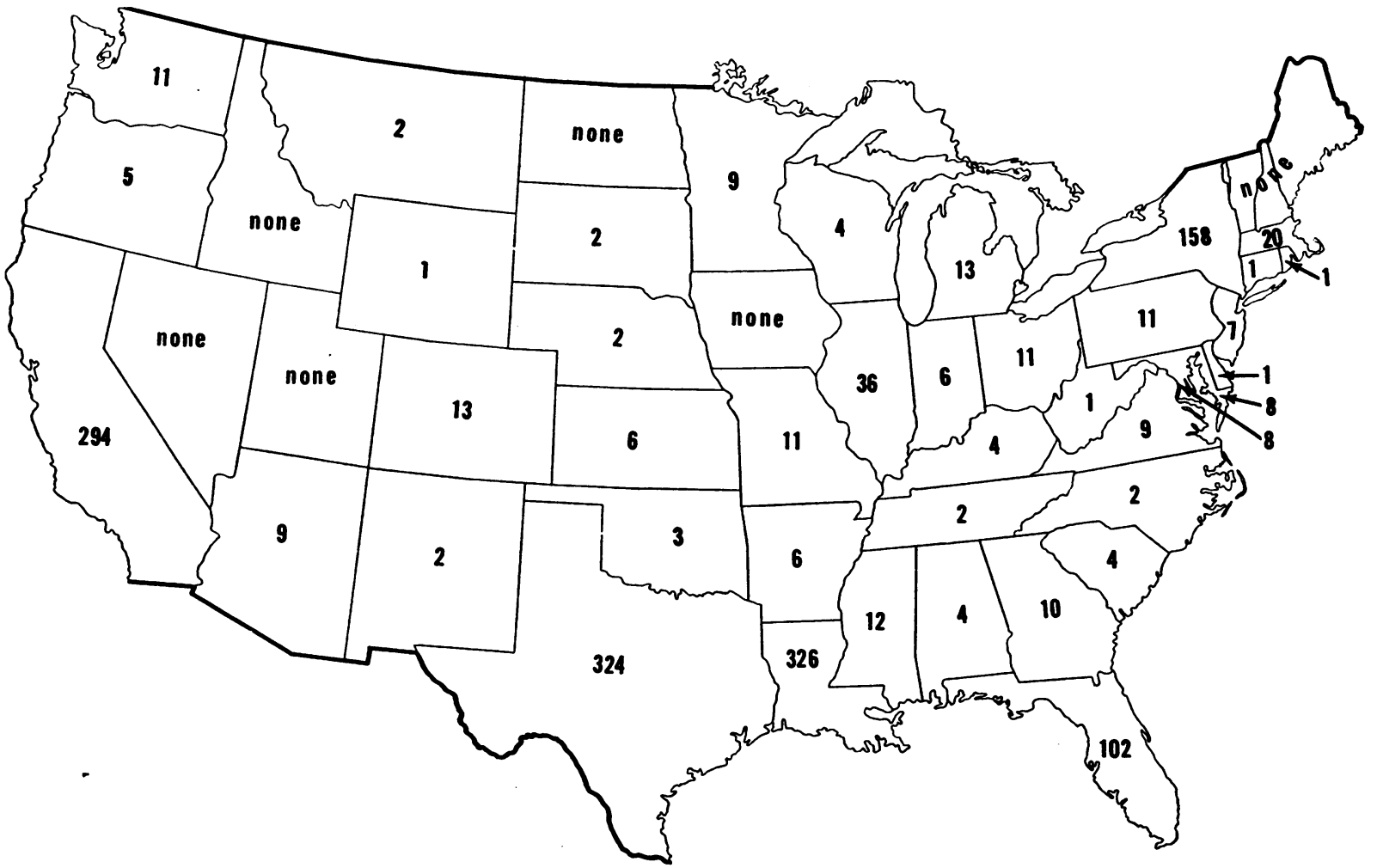

tients (80.6 percent) and of the New York patients (89.2 percent) were of foreign birth. The majority of the Florida patients (86.2 percent), of the Louisiana patients (95.4 percent), and of the Texas patients (74.8 percent) were born in the United States (table 1).

From 1940 through 1953, 476 patients were admitted to the leprosarium, as compared to 486 for 1931-40 and 503 for 1921-30. These figures suggest a slight downward trend. The decrease may be attributed in part, however, to the fact that in recent years patients with tuberculoid leprosy have not always been admitted to the leprosarium. The decrease is accounted for largely by a decrease in the number of foreign-born patients.

In addition to the patients admitted to the National Leprosarium, information has been obtained on 355 leprosy patients in the four endemic States who were not admitted. The number of patients in other States who were not admitted is at present unknown. Thus, a total of 1,820 patients were either admitted to the leprosarium or were known to have the dis- ease during the period 1921-53. It is impossible, however, to state with any degree of accuracy the total number of cases that actually occurred during that period.

\section{Foreign-Born Patients}

The 637 foreign-born leprosy patients admitted to the National Leprosarium give an idea of the extent to which leprosy has been imported into the United States in recent years. The majority of these patients probably became infected before they entered this country, and some of them were sources of infection in American-born patients. However, there is reason to believe that some of the foreign-born patients contracted the disease from infected associates after their arrival in the United States, as will be shown later in this paper.

Foreign-born patients have been admitted to the leprosarium from all sections of the country (table 1), and they have come from more than 50 different political entities (table 2). The majority of the foreign-born patients who 
Figure 2. Percentages of National Leprosarium patients of foreign birth and of United States birth, 1921-53.

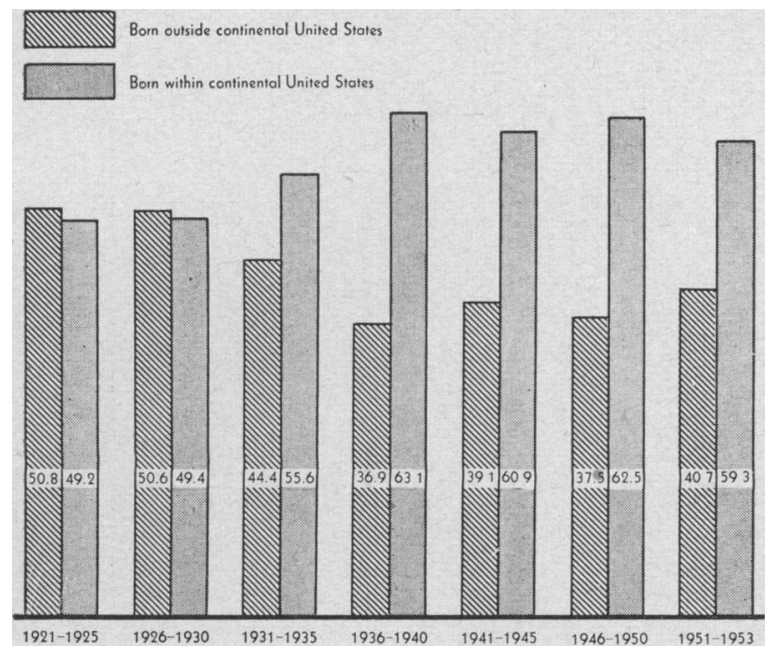

appeared in the Atlantic Coast States were born in European countries or the West Indies; of those who appeared in the Gulf Coast States, in the West Indies or Mexico; and of those in the
Pacific Coast States, in Mexico, the Pacific Islands, or Asia.

During the 33-year period, the number of patients of foreign birth declined more than the total number of patients fell. The yearly average number of foreign-born patients dropped from 25.0 during the period 1921-35 to 14.5 during the period 1936-53. There were 30.6 percent fewer foreign-born patients admitted during the second period than during the first. The greatest decrease, 67.7 percent, occurred among European-born patients. Patients native of Asia decreased 34.3 percent, and those native of the West Indies decreased 36.5 percent. Patients born in Puerto Rico, however, increased 100 percent, and those born in Mexico increased 22 percent.

A number of foreign-born persons in whom clinical leprosy developed after their arrival in the United States were not admitted to the leprosarium. In California, for example, 248 cases of leprosy were recognized among persons born in Mexico, but only 100 were admitted.

Table 1. Birthplace of National Leprosarium patients, according to State from which admitted, 1921-53

\begin{tabular}{|c|c|c|c|c|c|c|c|}
\hline State from which admitted & $\begin{array}{l}\text { Conti- } \\
\text { nental } \\
\text { United } \\
\text { States }\end{array}$ & $\begin{array}{c}\text { Foreign } \\
\text { coun- } \\
\text { tries }^{1}\end{array}$ & Total & State from which admitted & $\begin{array}{l}\text { Conti- } \\
\text { nental } \\
\text { United } \\
\text { States }\end{array}$ & $\begin{array}{l}\text { Foreign } \\
\text { coun- } \\
\text { tries }^{1}\end{array}$ & Total \\
\hline $\begin{array}{l}\text { Alabama } \\
\text { Arizona } \\
\text { Arkansas } \\
\text { California } \\
\text { Colorado } \\
\text { Connecticut } \\
\text { Delaware } \\
\text { District of Columbia } \\
\text { Florida } \\
\text { Georgia } \\
\text { Idaho } \\
\text { Ininois } \\
\text { Indiana } \\
\text { Kowansas } \\
\text { Kentucky } \\
\text { Louisiana } \\
\text { Maine } \\
\text { Maryland } \\
\text { Massachusetts } \\
\text { Michigan } \\
\text { Minnesota } \\
\text { Mississippi. } \\
\text { Missouri } \\
\text { Montana. }\end{array}$ & $\begin{array}{r}4 \\
6 \\
6 \\
57 \\
5 \\
0 \\
1 \\
5 \\
88 \\
8 \\
0 \\
13 \\
2 \\
0 \\
3 \\
2 \\
308 \\
0 \\
3 \\
1 \\
0 \\
2 \\
10 \\
6 \\
2\end{array}$ & $\begin{array}{r}0 \\
3 \\
0 \\
237 \\
8 \\
1 \\
1 \\
0 \\
3 \\
14 \\
2 \\
0 \\
03 \\
4 \\
0 \\
3 \\
2 \\
2 \\
15 \\
0 \\
5 \\
19 \\
13 \\
7 \\
2 \\
4 \\
0\end{array}$ & $\begin{array}{r}4 \\
9 \\
6 \\
294 \\
13 \\
1 \\
1 \\
8 \\
102 \\
10 \\
0 \\
36 \\
6 \\
0 \\
6 \\
4 \\
2326 \\
0 \\
8 \\
20 \\
13 \\
9 \\
12 \\
311 \\
2\end{array}$ & $\begin{array}{l}\text { Nevada } \\
\text { New Hampshire } \\
\text { New Jersey } \\
\text { New Mexico } \\
\text { New York } \\
\text { North Carolina } \\
\text { North Dakota } \\
\text { Ohio } \\
\text { Oklahoma } \\
\text { Oregon } \\
\text { Pennsylvania } \\
\text { Rhode Island } \\
\text { South Carolina. } \\
\text { South Dakota } \\
\text { Tennessee } \\
\text { Texas } \\
\text { Utah } \\
\text { Vermont } \\
\text { Virginia. } \\
\text { Washington } \\
\text { West Virginia } \\
\text { Wisconsin } \\
\text { Wyoming } \\
\text { Unknown }{ }^{5}\end{array}$ & $\begin{array}{r}0 \\
0 \\
1 \\
0 \\
17 \\
1 \\
0 \\
6 \\
3 \\
1 \\
3 \\
0 \\
4 \\
0 \\
2 \\
241 \\
0 \\
0 \\
3 \\
3 \\
0 \\
2 \\
0 \\
2\end{array}$ & $\begin{array}{r}0 \\
0 \\
6 \\
2 \\
141 \\
1 \\
0 \\
5 \\
0 \\
4 \\
8 \\
1 \\
0 \\
2 \\
0 \\
81 \\
0 \\
0 \\
6 \\
8 \\
1 \\
2 \\
1 \\
2\end{array}$ & $\begin{array}{r}0 \\
0 \\
7 \\
2 \\
158 \\
2 \\
0 \\
11 \\
3 \\
5 \\
11 \\
1 \\
4 \\
2 \\
2 \\
324 \\
0 \\
0 \\
9 \\
11 \\
1 \\
4 \\
1 \\
4\end{array}$ \\
\hline Nebraska & & 1 & 2 & Tota & 822 & 637 & 1,465 \\
\hline
\end{tabular}

1 Includes Territories and possessions of the United States. 2 Birthplace of 3 not recorded. ${ }^{3}$ Birthplace of 1 not recorded. 4 Birthplace of 2 not recorded. ${ }^{5}$ State from which admitted not recorded. 
The majority of the remaining 148 apparently returned to Mexico either voluntarily or through deportation procedures.

\section{American-Born Patients}

American-born patients were admitted from 33 States and the District of Columbia (table 1). Ten or more patients were admitted from only 7 States: the 4 endemic States and Illinois, Mississippi, and New York.

Not all of the American-born patients contracted the disease in this country, nor did all of them become infected in the States from which they were admitted. Many became infected while residing in endemic countries, and others, while residing in endemic States.

The number of American-born patients admitted to the leprosarium has been rather constant. The yearly average for 5-year periods from 1921-50 ranged from 22.4 to 31.0 , and the yearly average for 1951-53 was 18.0.

\section{Concéntration in States}

Leprosy among persons born in the United States is concentrated in Florida, Louisiana, Texas, and, to a lesser extent, California. Of the 820 American-born patients, 740 (90.2 percent) were either admitted from or born in these four States. A majority of the foreignborn patients were also admitted from these States, most of these, however, from California.

\section{Florida}

A total of 137 cases of leprosy were recognized among Florida residents during the period 1921-53. Admitted to the leprosarium were 102 of the patients.

Of the 137 patients, 111 were born in the continental United States and 96 were born in Florida. Thus, leprosy in Florida seems primarily to concern Florida-born persons.

Of the 22 patients of foreign birth, 16 were natives of the West Indies-11 of the Bahama Islands and 5 of Cuba. Of the 15 patients born in other States, 1 was a native of Louisiana, and 14 were natives of nonendemic States. (The birthplaces of 4 patients were not recorded.)
Table 2. Country of birth of foreign-born patients admitted to National Leprosarium, 1921-53

\begin{tabular}{|c|c|c|c|}
\hline Country of birth & 1921-35 & $1936-53$ & Total \\
\hline 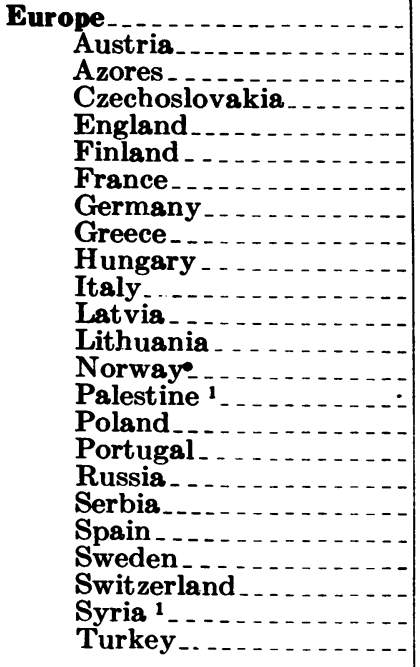 & \begin{tabular}{r|}
93 \\
1 \\
1 \\
$\mathbf{0}$ \\
$\mathbf{0}$ \\
$\mathbf{3}$ \\
$\mathbf{1}$ \\
$\mathbf{3}$ \\
$\mathbf{2 3}$ \\
$\mathbf{2}$ \\
$\mathbf{1 8}$ \\
$\mathbf{0}$ \\
$\mathbf{1}$ \\
$\mathbf{3}$ \\
$\mathbf{3}$ \\
$\mathbf{1}$ \\
$\mathbf{6}$ \\
$\mathbf{1 0}$ \\
$\mathbf{1}$ \\
$\mathbf{8}$ \\
$\mathbf{1}$ \\
$\mathbf{0}$ \\
$\mathbf{3}$ \\
$\mathbf{4}$
\end{tabular} & $\begin{array}{r}\mathbf{3 0} \\
\mathbf{0} \\
\mathbf{0} \\
\mathbf{1} \\
\mathbf{1} \\
\mathbf{0} \\
\mathbf{1} \\
\mathbf{2} \\
\mathbf{4} \\
\mathbf{0} \\
\mathbf{8} \\
\mathbf{1} \\
\mathbf{0} \\
\mathbf{1} \\
\mathbf{0} \\
\mathbf{0} \\
\mathbf{0} \\
\mathbf{3} \\
\mathbf{0} \\
\mathbf{5} \\
\mathbf{1} \\
\mathbf{1} \\
\mathbf{0} \\
\mathbf{1}\end{array}$ & \begin{tabular}{r|r}
123 \\
1 \\
1 \\
1 \\
1 \\
3 \\
$\mathbf{3}$ \\
$\mathbf{2}$ \\
$\mathbf{5}$ \\
$\mathbf{2 7}$ \\
$\mathbf{2}$ \\
$\mathbf{2 6}$ \\
$\mathbf{1}$ \\
$\mathbf{1}$ \\
$\mathbf{4}$ \\
$\mathbf{3}$ \\
1 \\
$\mathbf{1}$ \\
$\mathbf{6}$ \\
$\mathbf{1 3}$ \\
$\mathbf{1}$ \\
$\mathbf{1 3}$ \\
$\mathbf{2}$ \\
$\mathbf{1}$ \\
$\mathbf{3}$ \\
$\mathbf{5}$
\end{tabular} \\
\hline $\begin{array}{l}\text { Africa } \\
\text { Algeria } \\
\text { Cape Verde Islands } \\
\text { Malta } \\
\text { Morocen } \ldots\end{array}$ & $\begin{array}{l}\mathbf{5} \\
\mathbf{0} \\
\mathbf{3} \\
\mathbf{1} \\
\mathbf{1}\end{array}$ & $\begin{array}{l}2 \\
1 \\
\mathbf{0} \\
1 \\
\mathbf{0}\end{array}$ & $\begin{array}{l}\mathbf{7} \\
\mathbf{1} \\
\mathbf{3} \\
\mathbf{2} \\
\mathbf{1}\end{array}$ \\
\hline $\begin{array}{l}\text { Asia } \\
\text { China. } \\
\text { India } \\
\text { Japan } \\
\text { Korea }\end{array}$ & \begin{tabular}{r|}
35 \\
28 \\
4 \\
2 \\
1
\end{tabular} & $\begin{array}{r}23 \\
21 \\
1 \\
0 \\
1\end{array}$ & $\begin{array}{r}58 \\
49 \\
5 \\
2 \\
2\end{array}$ \\
\hline $\begin{array}{l}\text { Pacific Islands } \\
\text { Hawaiian Islands } \\
\text { Philippine Islands } \\
\text { Samoa (American) } \\
\text { Tahiti_. }\end{array}$ & $\begin{array}{r}68 \\
16 \\
49 \\
0 \\
3\end{array}$ & $\begin{array}{r}41 \\
10 \\
29 \\
2 \\
0\end{array}$ & $\begin{array}{r}109 \\
26 \\
78 \\
2 \\
3\end{array}$ \\
\hline $\begin{array}{l}\text { North America } \\
\text { Canada } \\
\text { Mexico }\end{array}$ & $\begin{array}{r}104 \\
4 \\
100\end{array}$ & $\begin{array}{r}123 \\
1 \\
122\end{array}$ & $\begin{array}{r}127 \\
5 \\
222\end{array}$ \\
\hline 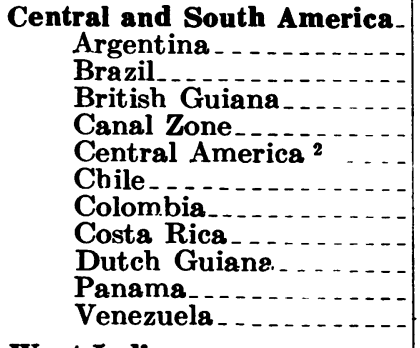 & \begin{tabular}{r|}
19 \\
1 \\
3 \\
5 \\
1 \\
1 \\
0 \\
1 \\
1 \\
4 \\
1 \\
1
\end{tabular} & $\begin{array}{l}\mathbf{9} \\
\mathbf{0} \\
\mathbf{1} \\
\mathbf{1} \\
\mathbf{0} \\
\mathbf{0} \\
\mathbf{1} \\
\mathbf{3} \\
\mathbf{0} \\
\mathbf{2} \\
\mathbf{1} \\
\mathbf{0}\end{array}$ & $\begin{array}{r}28 \\
1 \\
4 \\
6 \\
1 \\
1 \\
1 \\
4 \\
1 \\
6 \\
2 \\
1\end{array}$ \\
\hline $\begin{array}{l}\text { West Indies } \\
\text { British West Indies. } \\
\text { Cuba } \\
\text { Puerto Rico Ro } \\
\text { Virgin Islands... } \\
\text { Island not designated. }\end{array}$ & $\begin{array}{r}52 \\
27 \\
7 \\
11 \\
5 \\
2 \\
\end{array}$ & $\begin{array}{r}33 \\
6 \\
3 \\
22 \\
2 \\
0 \\
\end{array}$ & $\begin{array}{r}85 \\
33 \\
10 \\
33 \\
7 \\
2 \\
\end{array}$ \\
\hline Total $\ldots$ & 376 & 261 & 637 \\
\hline
\end{tabular}

1 Included with European countries because of its proximity.

2 Country not indicated. 
As shown by the following tabulation, there appears to be a slight downward trend in the number of patients native of the State:

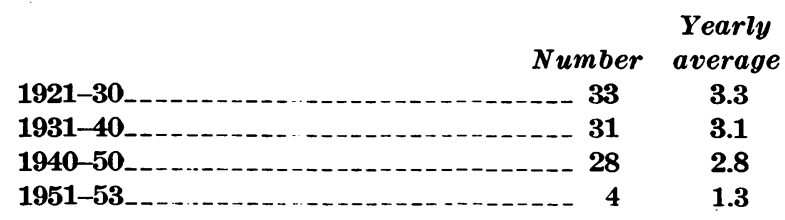

\section{Louisiana}

Leprosy was first recorded in Louisiana in 1766-68, when cases occurring among the French were isolated at Balize at the mouth of the Mississippi River (2). In 1785, a hospital was established in New Orleans for the treatment of persons afflicted with the disease, and in 1894, the Louisiana Home for Lepers was established near the village of Carville. In 1921, this institution was acquired by the Federal Government and became the National Leprosarium.

Both the West Indies and Canada have been considered as sources of leprosy in Louisiana. According to Dyer (3), "The popular impression ... that leprosy in Louisiana came with the Acadians from Nova Scotia . . was due, no doubt, to the fact that among the descendents of these people leprosy has existed, but the evidence seems to point to the fact that the disease came rather through the West Indies, particularly Martinique . . . and Cuba."

From 1921 through 1953, 350 cases of leprosy were recognized in the State, and 326 of the patients were admitted to the National Leprosarium.

As in Florida, leprosy in Louisiana is primarily a problem in persons born within the State: 313 of the 350 patients were born in Louisiana. Of the 18 patients born in other States, 6 were natives of Texas, 1 was born in California, and the remainder were natives of nonendemic States. Of the 15 foreign-born patients, 1 was born in Canada, 3 in Mexico, 1 in South America, and the remainder in Europe. (The birthplaces of 4 patients were not recorded.)

The trend in Louisiana-born patients also appears to be downward, as shown by the data below. There were 45.6 percent fewer cases recognized during the period 1941-50 than during the period 1921-30.

$\begin{array}{ccc}\text { Number } & \begin{array}{c}\text { Yearly } \\ \text { average } \\ 1921-30\end{array} \\ 1931-40 & 125 & 12.5 \\ 1941-50 & 68 & 10.9 \\ 1951-53 & 6.8 \\ & & \end{array}$

\section{T'exas}

In Texas, 393 cases of leprosy were recognized during the 33-year period. Of these patients, 324 were admitted to the National Leprosarium.

Information concerning the origins of the 69 patients not admitted to the leprosarium is unavailable. Of the 324 admitted, 241 were born within the continental United States, and of these, 202 were born in Texas and 17 in the adjoining endemic State of Louisiana. Of the 81 foreign-born patients, 77 were natives of Mexico. Thus, leprosy here concerns primarily natives of Texas, Mexico, and Louisiana.

The fact that rather large numbers of Texas patients were born in Mexico or Louisiana indicates that the disease in these areas is related. Further evidence is found in these facts: Of the 202 Texas-born patients, 39 had Mexican-born parents; 32 had one parent of Mexican birth; and 5 had one parent born in Louisiana.

The majority of the 39 Texas patients born in other States probably became infected after they entered Texas. Of 20 patients born in nonendemic States, 11 had lived only in these States prior to entering Texas. They entered Texas at ages ranging from 6 to 44 years, and experienced onset of the disease in from 7 to 51 years. Seven of the 20 had lived also in other endemic areas. Of the 17 Louisiana-born patients, 11 had lived only in that State but had had no known contact with the disease. When they moved, their ages ranged from early infancy to 69 years, and the onset of the disease occurred in from 2 to 56 years. One Louisianaborn patient experienced onset of the disease before he left that State; another had had contact with an infected relative; and three had lived also in endemic countries. Of 2 California-born patients, one experienced onset of the disease before leaving that State. (Histories for 4 of the 39 patients were incomplete.)

The number of Texas-born pacients admitted 
to the National Leprosarium has been rather constant.

\begin{tabular}{|c|c|}
\hline Number & $\begin{array}{c}\text { Yearly } \\
\text { average }\end{array}$ \\
\hline$-1-1-1-1-1-1$ & 1.6 \\
\hline $1926-30$ & 4.0 \\
\hline 1931-35 & 8.8 \\
\hline $1936-40$ & 6.6 \\
\hline $1941-45$ & 6.8 \\
\hline $1946-50$ & 8.8 \\
\hline $951-53$ & 6.3 \\
\hline
\end{tabular}

\section{California}

Cases of leprosy recognized in California numbered 521. A few more than half of the patients, 294, were admitted to the National Leprosarium. Of the 103 admissions during the period 1921-30, 31 occurred in 1922. Prior to 1921, California had its own leprosarium, and undoubtedly many of the patients admitted in 1922 had previously been hospitalized in that institution.

Leprosy in California is primarily a disease of the foreign-born. Of the 521 patients, 436 were of foreign birth, 41 were born in other States, and only 34 were born in California. (The birthplaces of 10 patients are not known.)

Foreign-born patients. The birthplaces of the foreign-born patients reflect the immigration pattern of the State: 394 of the patients were born in the Orient, the islands of the $\mathrm{Pa}$ cific, or Mexico. The greatest number, 248, were natives of Mexico.

Although most of the foreign-born patients probably became infected before they entered this country, it seems likely that a number of them contracted the disease after entry through contact with infected associates. This opinion is supported by the following data for Mexicanborn and Philippine-born patients on elapsed time between entry into the State and onset of the disease (patients who had experienced onset of the disease prior to leaving Mexico not included) :

\begin{tabular}{|c|c|c|}
\hline $\begin{array}{l}\text { Elapsed time } \\
\quad(\text { years })\end{array}$ & $\begin{array}{c}\text { Mexicans: } 91 \\
\quad(\text { percent })\end{array}$ & $\begin{array}{c}\text { Filipinos: } 40 \\
\text { (percent) }\end{array}$ \\
\hline Less than 10 & 30.7 & 82.5 \\
\hline Less than 15 & --57.1 & 87.5 \\
\hline More than 15 & 42.8 & 12.5 \\
\hline More than 20 & --- 29.6 & 2.5 \\
\hline
\end{tabular}

If it should be assumed that each of these patients became infected before entering the
United States, it must be assumed also that the incubation period, for some reason, was of much longer duration among the Mexicans than among the Filipinos. There are, however, two other possible explanations for the difference:

1. Many of the Mexicans may have become infected during visits to Mexico subsequent to their initial entry into the United States. Histories of such visits have been obtained for some of the patients. The Filipinos, on the other hand, are less likely to have made frequent visits to the islands of their birth.

2. Some of the Mexican-born patients may have become infected in California, where there was ample opportunity for contact with infectious cases.

The difference in the length of time between entry and onset is not because the Filipinos were younger than the Mexicans when they migrated to the State. In fact, the Filipinos were slightly older than the Mexicans, as shown by the following tabulation:

\begin{tabular}{|c|c|c|}
\hline $\begin{array}{c}\text { Age } \\
\text { (years) }\end{array}$ & $\begin{array}{l}\text { Mexicans } \\
\text { (percent) }\end{array}$ & $\begin{array}{l}\text { Filipinos } \\
\text { (percent) }\end{array}$ \\
\hline Under 10 & 10.9 & 2.2 \\
\hline Under 1 & 23.0 & 11.1 \\
\hline Under 20 & 46.1 & 37.7 \\
\hline Over 20 & 53.8 & 62.2 \\
\hline
\end{tabular}

The possibility that some of the Mexican-born patients in California contracted the disease after entry is further supported by the fact that the elapsed time between entry and onset for Mexicans admitted from California was considerably longer than the elapsed time for Mexicans admitted from nonendemic States, as shown below:

\begin{tabular}{|c|c|c|}
\hline $\begin{array}{l}\text { Elapsed time } \\
\text { (years) }\end{array}$ & $\begin{array}{c}\text { California: } 91 \\
\text { (percent) }\end{array}$ & $\begin{array}{c}\text { Nonendemic } \\
\text { States: \$Y } \\
\text { (percent) }\end{array}$ \\
\hline Less than 10 & 30.7 & 64.8 \\
\hline Less than $15_{-}$ & - 57.1 & 81.0 \\
\hline More than 10 & 42.8 & 35.1 \\
\hline More than 15 & 29.6 & 18.9 \\
\hline
\end{tabular}

American-born patients. The majority of the American-born patients in California probably became infected elsewhere, but a few may have contracted the disease in the State.

Of 34 patients born in California, 16 gave no history of having lived outside the State and may be assumed to have become infected in the State. Six of these 16 had had contact with cases in the family. 
Figure 3. Concentration of leprosy in Key West, Fla., 1921-53.

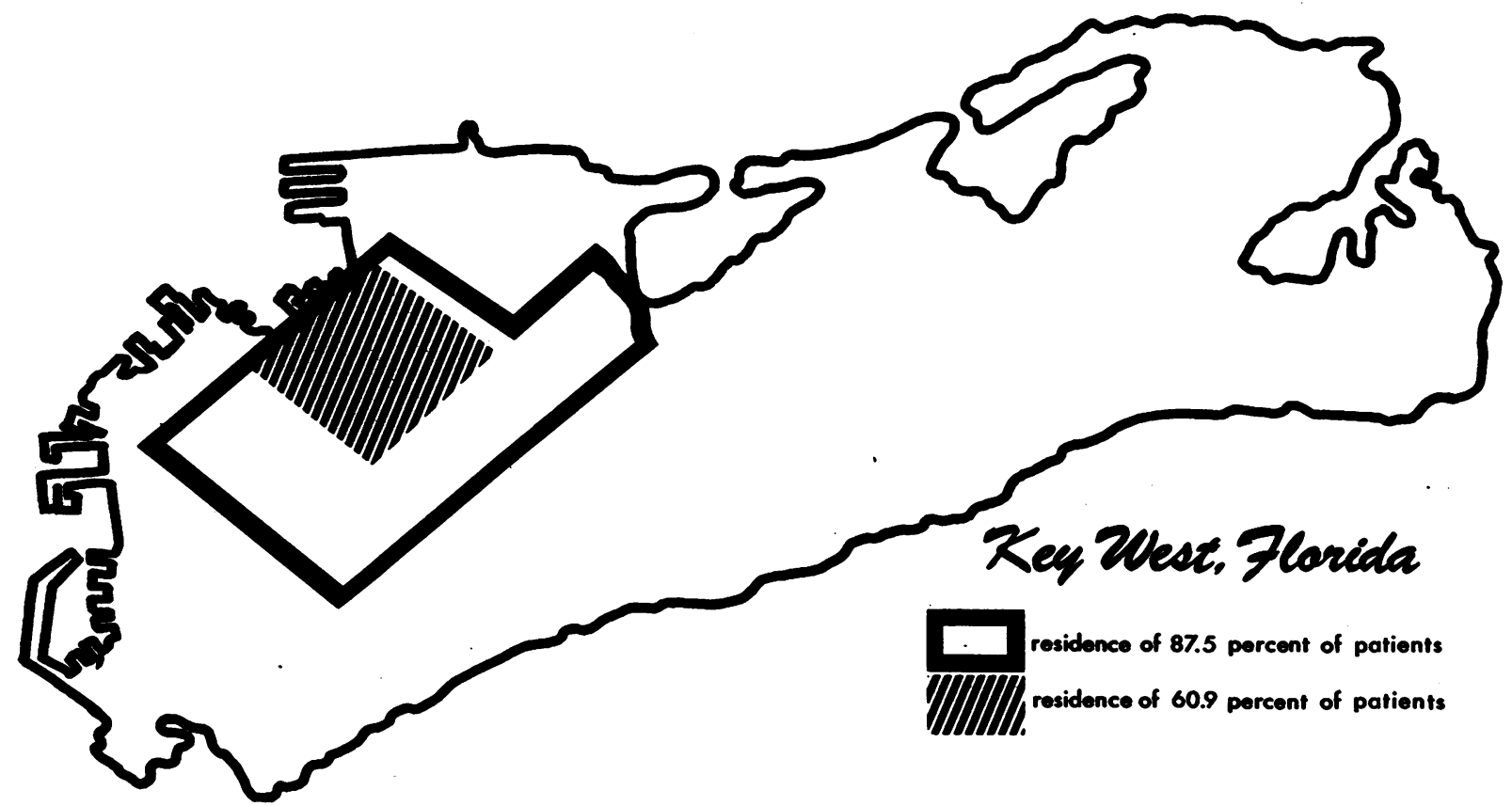

Of the 30 patients born in nonendemic States, 10 had not lived in an endemic State or country before entering California. One of these 10 had lived in Wisconsin, Oregon, and Washington. Six had lived only in Arizona, but onset of the disease occurred in 1 before he left that State, and in 2 others 4 to 6 years after they left. One had lived only in Ohio and Illinois, and one had lived only in Minnesota. The tenth had been a merchant seaman, visiting many ports in endemic countries, and experienced onset of the disease 6 years after he settled in California.

At least 6 of the 11 patients born in endemic States other than California probably became infected before they entered the State.

\section{Concentration in Limited Areas}

Not only is leprosy confined largely to a few States in this country, it is also confined to a limited area in each of these States.

In Florida, cases were recognized among residents of only 11 of the 67 counties during the 33-year period, and among residents of only 8 counties during the last 10 years of that period.

The disease has been concentrated in one county, Monroe, and within this county, in Key
West. Of the 137 cases in the State, 44.5 percent were recognized in Monroe County. Of the 96 Florida-born patients, 44.5 percent resided in Key West at the time of diagnosis. Moreover, case histories for 94 Florida-born patients indicate that 78 of these patients probably contracted the disease in Key West.

Within Key West, the disease has been concentrated in a restricted section of the city. Of the 65 patients residing in the city while the disease was active, 56 lived within the outlined area on the map in figure 3 , and 39 lived within the shaded area, an area about 5 blocks square. (The address of one patient was not determined.)

In Louisiana, the disease has been concentrated in the lower half of the State. Of the total of 350 patients, 95.1 percent resided in this section: 71.7 percent, in the 9 parishes in the southeastern part of the State; and 46 percent, in Orleans Parish. Cases have been recognized in 27 of the 35 parishes in the southern half of the State, but in only 4 of the 29 in the northern half.

The disease in Texas has been concentrated in the southeastern part of the State. Patients were admitted to the National Leprosarium 
from only 53 of the 254 counties. More than 10 patients were admitted from only 7 counties; the patients from these $\tau$ counties represented 68.2 percent of the total from the State. Only 1 patient was admitted from each of 23 other counties.

The 521 patients in California resided in 33 of the 58 counties when they were admitted to the leprosarium or when the disease was recognized. Ten or more patients resided in 11 of the counties, and 293 patients lived in San Francisco or I os Angeles County. There has not been as definite a concentration of cases in limited areas in California as in the other endemic States, but, as noted previously, many of the California patients apparently were infected outside the State.

This concentration of leprosy in limited areas is important because in many instances it is related to the possible source of infection. Particularly is this true in the consideration of the source of infection in members of the armed forces. There is a tendency to consider the source of infection of a serviceman who was born in or had lived in one of the endemic States as that State regardless of whether or not he later spent time in another endemic State or in an endemic country. Actually, if he had lived only in the northwestern part of Texas, for example, his opportunity for becoming infected was no greater than if he had lived in Colorado or Oklahoma.

\section{Dispersion From Endemic States}

Leprosy in the endemic States is also important as it relates to the disease in the nonendemic States. Forty-six patients born in the endemic States were admitted from 19 nonendemic States and the District of Columbia (fig. 4). Eight were born in Florida; 14 in Louisiana; 15 in Texas; and 9 in California.

The majority of these 46 patients probably became infected before they left their State of birth, and in some instances they have been sources of infection in persons living in nonendemic States. In 16 of the patients, the disease had become clinically manifest before they left their State of birth. Another 4 patients entered the armed services directly from the State of birth, and in each of these the onset occurred within 2 years after they entered the service.

Eleven patients had lived only in nonendemic States after they left their State of birth and before the disease became manifest. In 4 of these the onset of the disease occurred within 4 years after they left their State of birth; in 8 , within 15 years; and in 3 , after more than 15 years.

From the histories of 7 of the 46 patients, it seems likely that they became infected while in foreign countries: Three had served as members of the armed forces in the Philippine Islands; two had lived in China; one in Japan; and one in Hawaii. The histories of the remaining 8 patients are insufficient for analysis.

\section{Nonendemic States}

During the period 1921-53, 415 patients were admitted to the National Ieprosarium from 36 nonendemic States and the District of Columbia. Of these, 288 were born outside continental United States and 126 were natives of the United States. (The birthplace of one is not known.)

Of the foreign-born patients, 140 were admitted from New York State and 148 were admitted from 28 other nonendemic States and the District of Columbia. The greatest number of the foreign-born patients were natives of Mexico, and the next greatest number were natives of the West Indies.

The 126 American-born patients, who were admitted from 29 nonendemic States and the District of Columbia, may be categorized as follows:

Born in endemic States_._.

Born in nonendemic States, resided in endemic areas prior to onset of disease 46

Born in nonendemic States, visited or traveled in endemic areas prior to onset of disease

Born in nonendemic States, served as members of armed forces in endemic areas prior to onset of disease

Born in nonendemic states, resided only in nonendemic States.

Incomplete history 33

The majority of these patients had opportunities for becoming infected while in an endemic State or foreign country. The $46 \mathrm{pa}$ - 
Figure 4. Nonendemic States from which patients born in endemic States were admitted to the National Leprosarium, 1921-53.

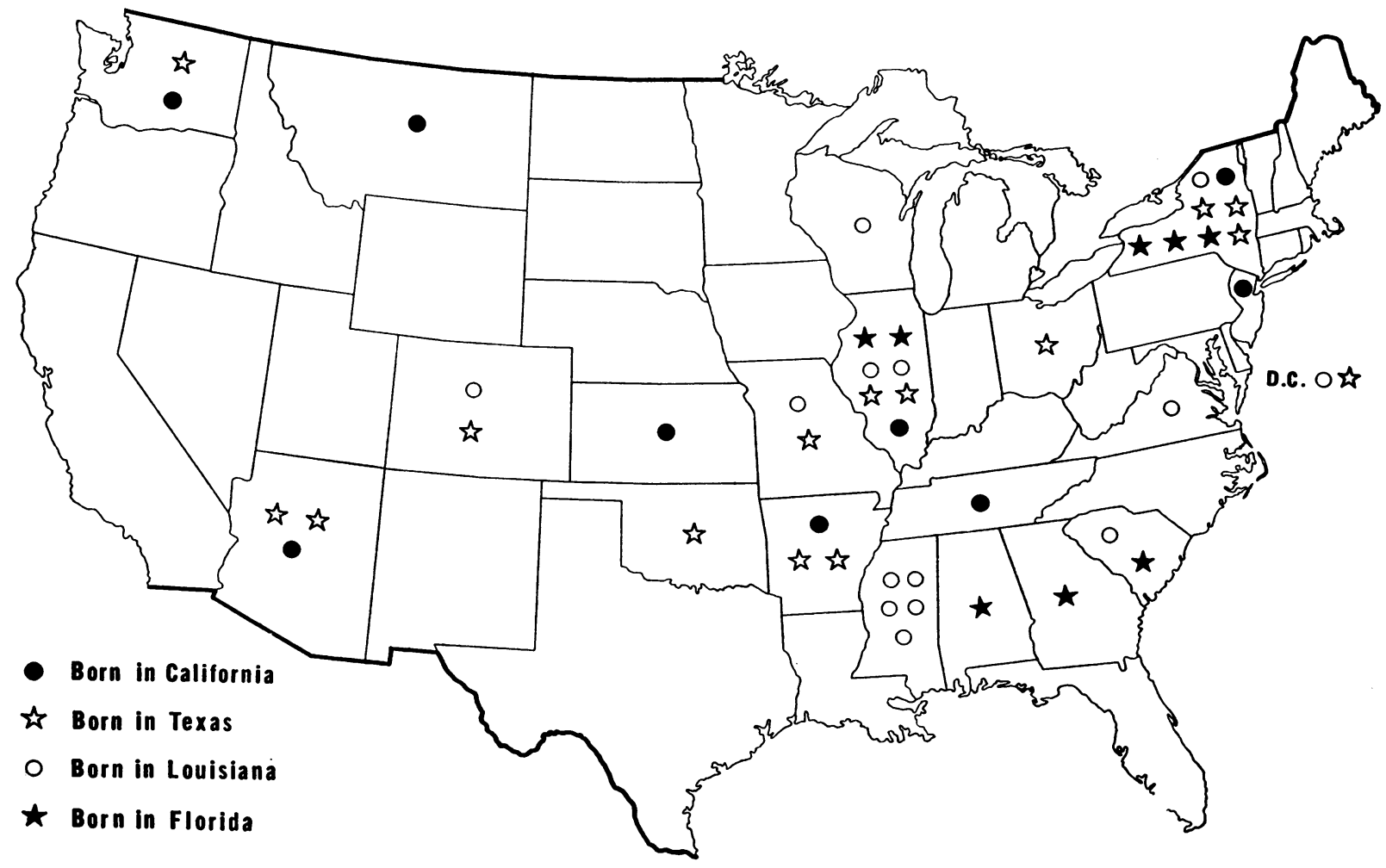

tients born in endemic States have already been discussed. In several of the 20 who lived in endemic areas sometime after birth, the onset of the disease occurred before they left the area, and in others, shortly afterward. The 18 patients who had served in endemic areas as members of the armed forces experienced onset of the disease in from 1 to 13 years after such duty: In 9 , the onset occurred within 5 years; in 15 , within 10 years; and in 17 , within 15 years (date of onset not given for 1 patient).

If the histories of the 33 patients who specified that they had never lived or visited in an endemic area are correct, it must be assumed that they became infected while living in nonendemic States. Nine of them gave definite histories of contact with known cases of leprosy in the nonendemic State. The possibility exists, of course, that some of the patients had visited in endemic areas but failed to give such information to the interviewers.

A majority of families in the United States in which the disease is recognized are single- case families, and the sources of infection are apparently extrafamilial infectious cases. With such low prevalence of the disease in the nonendemic States, it is not surprising that so few cases have occurred. Undoubtedly, if there were areas in these States in which the disease was concentrated as it is in the endemic States, more cases would occur.

Of the patients who had never lived in an endemic State, the number who had lived only in northern States is about the same as the number who at some time had lived in the southern States. This strongly indicates that, providing there is ample opportunity for contact with the disease, it would occur in any part of the country, north or south.

\section{New York State}

The leprosy situation in New York is unique in that, although the disease is not endemic, a large number of patients have been admitted from the State. 
The reporting of leprosy is not required in New York State, although it is in New York City. P'ersons with the disease are not always admitted to the National Ieprosarium. Occasionally, persons residing in endemic States move to New York when they learn that they have the disease, and a few patients have absconded from the leprosarium to that State. Information on many of these persons, however, is insufficient for analysis; the following discussion therefore relates only to patients originally admitted to the leprosarium from New York.

Of the 158 patients admitted from New York, 140 were of foreign birth and only 18 were born within continental United States. Of the latter, only 2 were born in New York.

From the available information concerning the American-born patients, the majority probably became infected before entering the State. One patient, however, almost certainly became infected in the State. He had lived in New York City until the age of 42 years (1923), when be visited in Italy for 3 months. On his return the disease was recognized, and he was sent to the leprosarium from the Immigration Station. The onset of the disease had occurred in 1921. Another patient may have become infected in New York. Born in Tampa, this parient moved to New York at the age of 6 . years. There he lived with his aunt, who had moved to New York from Florida a year after she developed clinical manifestations of leprosy. The aunt was admitted to the leprosarium 6 years after moving to New York, and 9 years later onset of the disease occurred in the nephew.

Of the foreign-born patients, the greatest number, 59, were natives of the islands of the West Indies, and the next greatest number, 34, were natives of the countries of Europe. As in California, it seems likely that some of the foreign-born patients in New York contracted the disease after entry into this country. With 158 patients admitted to the leprosarium and many more not admitted, there has been ample opportunity for contact with infectious cases within the State. Nearly one-half (47.4) of the patients admitted were admitted more than 5 years after the onset of the disease; 17.5 percent, more than 10 years after onset. As shown in the following tabulation, the length of time between entry into this country and onset of the disease was considerably longer for Europeanborn patients than for patients born in the West Indies :

\begin{tabular}{|c|c|c|}
\hline $\begin{array}{c}\text { Elapsed time } \\
\text { (years) }\end{array}$ & $\begin{array}{c}\text { Europeans: } 24 \\
(\text { percent })\end{array}$ & $\begin{array}{c}\text { West Indians: } 35 \\
\quad(\text { percent })\end{array}$ \\
\hline Less than 10 & 33.3 & 82.8 \\
\hline Less than 15 & $-\ldots 66.6$ & 94.2 \\
\hline More than 15 & --33.3 & 5.7 \\
\hline More than 20 & --25.0 & 2.8 \\
\hline More than 30 & $-\ldots \quad 8.3$ & 0 \\
\hline
\end{tabular}

Based only on the number of admissions to the leprosarium, the trend of the disease in New York is downward. There were 51 percent fewer patients admitted during the period 1936-53 than during the period 1921-35. Patients of European birth decreased 82.7 percent, and those of West Indian birth, 15.6 percent. Although the number of patients from Puerto Rico is small, patients native of this island increased 70 percent. Whether the apparent downward trend is actual or due to a decrease in the admission of recognized patients is not known.

\section{Summary}

Leprosy in the United States is a definite, though not a great, public health problem. The disease may occur in, and be transmitted in, any section of the country. Although a large proportion of the recognized cases have occurred in persons of foreign birth, a majority have occurred in natives of the United States. It must not be assumed, however, that all the patients of foreign birth became infected before entry into the United States, although a majority probably did. In the majority of American-born patients, the disease was contracted in this country.

A majority of the cases have occurred among residents of New York, Florida, Iouisiana, Texas, and California, and most of the American-born patients have been natives of Florida, Louisiana, or Texas. The disease has been concentrated in restricted areas of Florida, Louisiana, Texas, and California. A number of patients recognized in the nonendemic States became infected in the endemic States. 


\section{REFERENCES}

(1) Romans, B.: Concise natural history of East and West Florida. Printed for the author in New York, 1775.

(2) Denny, O. E.: Leprosy in the southern United States. South. M. J. 26: 763-68 (1933).
(3) U. S. Congress. Senate Committee on Public Health: Care and treatment of persons afflicted with leprosy. Report of the Committee [on Public Health], 64th Cong., 1st Sess. Washington, D. C., U. S. Government Printing Office, 1916, p. 13 .

\section{Infernational Conference on Arid Lands}

The need for a unified research approach to problems of water supply and food production in areas where water is scarce was stressed at the International Symposium and Conference on the Future of Our Arid Lands.

The meetings, held at Albuquerque and Socorro, N. Mex., from April 26 to May 4, 1955, were sponsored by the American Association for the Advancement of Science and its Southwestern and Rocky Mountain Division and were supported by the National Science Foundation, the Rockefeller Foundation, and the United Nations Educational, Scientific, and Cultural Organization.

Col. Omar Draz of the Egyptian Army Veterinary Corps, director, desert range development project, Desert Institute, Heliopolis, Egypt, in his address on the adaptation of plants and animals to arid conditions said, "The growing world population, together with the need to raise the standard of living for millions of people who suffer hunger or malnutrition, makes the increase of the world food production an urgent and vital requirement."

The symposium consisted of four technical sessions on : variability and predictability of water supply in arid regions; improved use of present resources; prospects for additional water sources, including questions on the practicability of weather control, demineralizing saline water, and re-using waste waters; and adaptation of plants and animals to arid conditions.

The American Association for the Advancement of Science will publish the symposium papers and specific recommendations of the conference. Further information may be obtained from John A. Behnke, Associate Administrative Secretary, American Association for the Advancement of Science, 1025 Connecticut Avenue, N. W., Washington 6, D. C. 